\title{
Development of Reading Materials Environment-Based in VII Grade Students of Junior High School (SMPN) 1 Kuala, Indonesia
}

\author{
Abram Thiofilus Sitepu', Mutsyuhito Solin², Arif Rahman ${ }^{2}$ \\ ${ }^{1}$ Master Student in State University of Medan (Unimed), Medan, Indonesia \\ ${ }^{2}$ Lecturer in State University of Medan (Unimed), Medan, Indonesia \\ abram.aditian@gmail.com
}

\begin{abstract}
This study aims is to find out the development of reading material by using environment base in Junior High School (SMPN) 1 Kuala. The research study used quantitative method by using sample in VII grade student Data with total 160 students from 5 clasess. The result show multiple intelligences based writing modules is more effective in improving student learning outcomes, this is indicated by the learning outcomes of students who are taught to use a module developed which is higher by 2460 with an average of $76.75 \%$ compared to the average value of students using 2220 textbooks. an average of $69.12 \%$.
\end{abstract}

Keywords : development; reading material; environment-based

\section{Introduction}

Indonesian languange is a subject that can support the success of students in learning other knowledge that taught in school. In order to be more meaningful, learning Indonesian must be tailored to the interests, abilities and needs of students and their environment so that the potential in students can develop. Reading is a person's process in reconstructing a message. By optimizing students' reading skills, Indonesian children will not experience lagging with other countries. Based on PIRLS of 2012 for Reading Rating Scale 2012, Indonesia was ranked 64th out of 65 countries. The differences in ability of each individual get the teacher to engage in terms of student learning details. Teacher pedagogical competence in terms of guiding the understanding of a reading is urgently needed. Piaget (in Majid, 2015:9) stated that each child has its own way of interpreting and adapting to its living environment.

In the world of education, books are an important part of supporting the survival of education. With the existence of adequate textbooks the implementation of learning-teaching activities becomes more fluid. The teacher can perform his duties at maximum with the help of books. Likewise students, knowledge gained will be more meaningful in the presence of a mix of sciences from teachers and books. Hence, the existence of quality teaching materials is important in assisting teachers and students in educational activities. Muslich (2010:21) states that teaching materials are said to have positive terms when (1) can expand child insight, (2) add new knowledge, (3) guide constructive thinking, (4) direct creativity, (5) foster good moral, social, and religious attitudes, and (6) demand toward a more self-sufficient life.

The Indonesian subject is divided into four skills. The four skills are reading, writing, listening, and speaking. Each of those skills is further divided into a group of language and literature. In learning-teaching activities, however, reading skills have not been maximal. It can be seen from the results of the PIRLS survey for Reading Rating Scale 2012, Indonesia was ranked 64th out of 65 countries. In addition, students only refuse when given assignments by the teacher. A book is needed that is able to integrate basic competencies based on the environment in order to streamline the time of teaching and learning activities. With the existence of teaching materials for reading comprehension based on environment students will obtain the full knowledge and skills so that learning will become more meaningful. Meaning means that in integrated learning, students will be able to understand the concepts they learn 
through direct experience with their environment and can provide effectiveness between concepts in intra-subjects and between subjects.

Sasmi Farida's research on the factors that cause reluctance to read in the student environment shows that the survey results were $82.46 \%$ of students or 47 people stated that they did not need to read books or go to the library if they had to do assignments, they were just browsing the internet and the assignments were finished. One respondent when interviewed stated that the teacher's assessment of assignments in class was not strict. Tasks are collected only as a prerequisite, so that the important task is completed and collected on time.

\section{Review of Literature}

\subsection{Modules}

Majid (2011: 176) explains that "Modules are a book written with the aim that students can learn independently without the guidance of the teacher, so that the module contains at least all the basic components of teaching materials." A module will be meaningful if students can easily use it. Learning with modules allows a student who has high speed in learning will more quickly complete one or more basic competencies compared to other students. Thus, the module must describe the basic competencies that will be faced by students, presented using good, interesting language, equipped with illustrations. Trianto (2011: 227) explains that "Student books (modules, dictates) are guidebooks for students in learning activities that contain subject matter, investigation activities based on concepts, scientific activities, information, and examples of the application of science in everyday life ."

Depdiknas (2008:20) defines that "Modules are a systematically presented set of teaching materials so that their users can learn with or without a facilitator or teacher. Thus a module should be able to be used as a teaching material in place of the teacher's function." If the teacher has the function of explaining something then the module should be able to explain something with a language that learners readily accept according to the level of knowledge and age. Purwanto, Rahadi, Lasmono (2007:9) said that "Module is a systematically designed learning material based on a particular curriculum and packaged in the form of the smallest learning unit and allows to be studied independently in a given unit of time.

\subsection{Environment-Based Learning}

Learning is an attempt made by a teacher to teach learners to have certain knowledge and skills according to what it learns. This process contains the direction a teacher makes to learners to perform a learning action that can build and produce knowledge, skills, and attitudes on him so that a behavioral change manifests in a learning result. In relation to the environment making environmentally based learning should be designed in such a way that there is an expected learning process as well as the achieved learning goal as desired. According to Syukri (2013:69) the implementation of environmental education is the same as that of education in the other fields of science, which is to be able to teach students. It was also put forward by Joseph in (Syukri, 2013:69), but in his learning was about to use an integrative approach.

So that their application in each of the derived subjects from different disciplines, certainly heavily dependent on the content of the material to be taught that in it is closely related to environmental problems. Here the messages of environmental education in the form of knowledge, skill, attitude, and caring can be conveyed without reducing the meaning of 
learning activities to the subject matter of the principal disciplines concerned. So it can be said that environmental education is interdisciplinary.

\section{Research Method}

The study was conducted in VII Grade Junior High School (SMPN) 1 Kuala. Which is located on Gajah Mada Road No. 1 Kuala, Kec. Kuala, Kab. Rank Sumatera Utara. The selection of the in this study is school with consideration of time, power, and expense.

The population VII Grade Junior High School (SMPN) 1 Kuala Learning students 2018/209. As for the number of student VII Grade populations of odd semesters of 2018/2019 learning year which number 5 classes namely: VII A, VII B, VII C, VII D and VII E with an overall number of 160 students. Of the entire population determined samples namely VII A and VII B as field trial classes. VII C and VII D Grade as individual trials and class VII E as small group trials. Sampling is done by random sampling.

\section{Discussion}

The preparation of modules that have a reading load on the understanding of the report text of the results of the environment-based observation that was developed was compiled based on module needs analysis first. First, the needs analysis carried out is to provide a questionnaire of needs aimed at students to see what skills students already have and what students do not have. Second, look at the extent to which knowledge is mastered by students, especially in the observation report text material.

Next, conduct a 2013 curriculum analysis and the need for teaching materials from the syllabus which requires a module to support learning Indonesian. After that, analyze the Core Competencies (KI), Basic Competencies (KD), and prepare the RPP (Learning Implementation Plan).

After carrying out the analysis, the next step is to compile material content on the developed environment-based reading comprehension module which contains the title (module title is determined on the basis of KDs or learning material contained in the syllabus, one competency can be used as a module title if competence is not too large, while the magnitude of competence can be detected, among others, by means if described into the subject matter), learning instructions (student / teacher instructions, concept maps), competencies to be achieved, supporting information, exercises, work instructions (can be worksheets ), and evaluation / assessment.

The development of an environment-based understanding reading module intended in this study is the development of a modified module in the process of applying environmental strategies that uses eight types of intelligence, consisting of (1) verbal-linguistic intelligence (word smart), (2) visual-spatial intelligence (picture smart), (3) musical-rhythmic intelligence (musical smart), (4) interpersonal intelligence (smart people), (5) intrapersonal intelligence (self smart), (6) physical-kinesthetic intelligence (body smart), ( 7) logical-mathematical intelligence, and (8) naturalist intelligence. 
Table 1. Necessary Data Analyis

\begin{tabular}{|c|c|c|c|c|c|c|}
\hline \multirow[t]{2}{*}{ No. } & \multirow[t]{2}{*}{ Questions } & \multirow[t]{2}{*}{ Answers } & \multicolumn{3}{|c|}{ Frequency } & \multirow[t]{2}{*}{ Percentage } \\
\hline & & & Teacher & Students & Total & \\
\hline \multirow[t]{2}{*}{1} & \multirow{2}{*}{$\begin{array}{l}\text { Get to know the } \\
\text { teaching materials in } \\
\text { the form of modules }\end{array}$} & Yes & 3 & 4 & 7 & $20 \%$ \\
\hline & & No & - & 28 & 28 & $80 \%$ \\
\hline \multirow[t]{2}{*}{2} & \multirow{2}{*}{$\begin{array}{l}\text { Using teaching } \\
\text { materials in the form } \\
\text { of modules }\end{array}$} & Yes & - & - & - & - \\
\hline & & No & 3 & 32 & 35 & $100 \%$ \\
\hline \multirow[t]{2}{*}{3} & \multirow{2}{*}{$\begin{array}{l}\text { Requires } \\
\text { environment-based } \\
\text { teaching materials in } \\
\text { the form of modules in } \\
\text { the learning process }\end{array}$} & Yes & 3 & 32 & 35 & $100 \%$ \\
\hline & & No & - & - & - & - \\
\hline
\end{tabular}

Based on the table above regarding the analysis of needs by teachers and students conclusions are obtained as follows:

a. Most students $(80 \%)$ stated that they were not familiar with teaching materials in the form of modules, while all teachers and a small number of students $(20 \%)$ stated that they were familiar with teaching materials in the form of modules.

b. Teachers and students do not use teaching materials in the form of modules in the learning process.

c. All teachers and students stated that they needed environment-based teaching materials in the form of modules in the learning process.

Table 2. Environmental Based Understanding Module Reading Expert Assessment for Content Feasibility

\begin{tabular}{|c|c|c|c|}
\hline Sub Component & Indicator & $\begin{array}{c}\text { Score } \\
\text { Average }\end{array}$ & Criteria \\
\hline $\begin{array}{l}\text { 1. Conformity and } \\
\text { Depth of Concept }\end{array}$ & 1. Material breadth & 100 & Very good \\
\hline $\begin{array}{ll}\text { with } & 2013 \\
\text { Curriculum } & \\
\end{array}$ & 2. Material depth & 100 & Very good \\
\hline \multirow[t]{2}{*}{ 2. Material accuracy } & $\begin{array}{l}\text { 3. The accuracy of facts and } \\
\text { concepts }\end{array}$ & 87,5 & Very good \\
\hline & 4. Illustration accuracy & 75 & Good \\
\hline \multirow[t]{2}{*}{$\begin{array}{l}\text { 3. Learning Support } \\
\text { Materials }\end{array}$} & $\begin{array}{l}\text { 5. Material conformity with } \\
\text { the development of } \\
\text { science. }\end{array}$ & 100 & Very good \\
\hline & $\begin{array}{ll}\text { 6. } & \text { Presentness of features } \\
\text { (description and exercise), } \\
\text { examples and referrals }\end{array}$ & 87,5 & Very good \\
\hline
\end{tabular}




\begin{tabular}{|l|l|c|c|}
\hline & \begin{tabular}{l} 
7. Contextual \\
\cline { 2 - 4 }
\end{tabular} & 100 & Very good \\
\cline { 2 - 4 } & $\begin{array}{l}\text { Indonesian, Environment, } \\
\text { Technology, and Society }\end{array}$ & 87,5 & Very good \\
\hline Total of Average Score & 92,19 & Very good \\
\hline
\end{tabular}

Table 3. Assessment of Module Material Experts Reading Environment-based understanding for Presentation Feasibility

\begin{tabular}{|c|c|c|c|}
\hline Sub component & Indicator & $\begin{array}{l}\text { Average } \\
\text { Score }\end{array}$ & Criteria \\
\hline \multirow{5}{*}{$\begin{array}{l}\text { 1. } \text { Module } \\
\text { Presentation } \\
\text { Technique }\end{array}$} & $\begin{array}{l}\text { 1. The module presents the } \\
\text { material according to KI/KD. }\end{array}$ & 100 & Very good \\
\hline & $\begin{array}{l}\text { 2. The module presents material } \\
\text { that fits the needs of learners }\end{array}$ & 100 & Very good \\
\hline & $\begin{array}{l}\text { 3. The module provides } \\
\text { motivation to learners. }\end{array}$ & 100 & Very good \\
\hline & $\begin{array}{l}\text { 4. The module provides } \\
\text { interactivity (stimulus and } \\
\text { response) to learners. }\end{array}$ & 100 & Very good \\
\hline & $\begin{array}{l}\text { 5. The module presents complete } \\
\text { information. }\end{array}$ & 100 & Very good \\
\hline \multirow[t]{2}{*}{$\begin{array}{l}\text { 2. Presentation } \\
\text { and Learning }\end{array}$} & $\begin{array}{l}\text { 6. Developing the concept of } \\
\text { living environment learning. }\end{array}$ & 100 & Very good \\
\hline & 7. Notices aspects of job safety. & 100 & Very good \\
\hline \multirow[t]{3}{*}{$\begin{array}{l}\text { 3. Completion } \\
\text { Presentation }\end{array}$} & $\begin{array}{l}\text { 8. The module's introduction is } \\
\text { accompanied by a topic, } \\
\text { explaining the subject matter, } \\
\text { the importance of the topic and } \\
\text { achievement of competence as } \\
\text { well as indicators according to } \\
\text { the } 2013 \text { Curriculum. }\end{array}$ & 100 & Very good \\
\hline & $\begin{array}{l}\text { 8. The list of contents that are } \\
\text { subtracted from the important } \\
\text { parts of the module and sub-sub } \\
\text { along with its page number. }\end{array}$ & 100 & Very good \\
\hline & $\begin{array}{l}\text { 9. Equipped with Glossary and } \\
\text { concept map }\end{array}$ & 100 & Very good \\
\hline \multicolumn{2}{|r|}{ Total Average score } & 100 & Very good \\
\hline
\end{tabular}


Table 4. Environmental Based Reading Material Module Expert Assessment

\begin{tabular}{|c|c|c|c|}
\hline Sub component & Indicator & $\begin{array}{c}\text { Average } \\
\text { score }\end{array}$ & criteria \\
\hline \multirow[t]{2}{*}{ 1. Apperception } & $\begin{array}{l}\text { 1. The module develops student } \\
\text { apperception which consists of ice } \\
\text { breaking, fun story, music, and } \\
\text { brain gym. }\end{array}$ & 100 & Very good \\
\hline & $\begin{array}{l}\text { 2. Modules contain scene settings } \\
\text { that aim to build learning } \\
\text { concepts, provide learning } \\
\text { experiences before entering the } \\
\text { core material, as instructions and } \\
\text { generate interest and curiosity of } \\
\text { students before learning. }\end{array}$ & 87,5 & Very good \\
\hline \multirow[t]{2}{*}{ 2. Strategy } & $\begin{array}{l}\text { 3. Modules present different } \\
\text { strategies for each material to } \\
\text { arouse student interest. }\end{array}$ & 100 & Very good \\
\hline & $\begin{array}{l}\text { 4. Modules explain the environment } \\
\text { approach in learning. }\end{array}$ & 100 & Very good \\
\hline \multicolumn{2}{|r|}{ Total Average Score } & 96,87 & Very good \\
\hline
\end{tabular}

Table 5. Expert Assessment of Material Modules based on Environmental Reading for Language Aspects

\begin{tabular}{|c|c|c|c|}
\hline Sub component & Indicator & $\begin{array}{c}\text { Average } \\
\text { Score }\end{array}$ & Criteria \\
\hline \multirow[t]{8}{*}{$\begin{array}{l}\text { 1. Presentation } \\
\text { Completeness }\end{array}$} & $\begin{array}{l}\text { 1. The language used invites } \\
\text { interactive students. }\end{array}$ & 100 & Very good \\
\hline & $\begin{array}{l}\text { 2. The language used is standard } \\
\text { and interesting. }\end{array}$ & 100 & Very good \\
\hline & $\begin{array}{l}\text { 3. The language or sentence used } \\
\text { is easily understood by } \\
\text { students. }\end{array}$ & 87,5 & Very good \\
\hline & $\begin{array}{l}\text { 4. Can develop the environment } \\
\text { of students. }\end{array}$ & 87,5 & Very good \\
\hline & $\begin{array}{l}\text { 5. Use language according to the } \\
\text { child's maturity level. }\end{array}$ & 87,5 & Very good \\
\hline & $\begin{array}{l}\text { 6. Using a clear sentence } \\
\text { structure. }\end{array}$ & 100 & Very good \\
\hline & $\begin{array}{l}\text { 7. Avoid questions that are } \\
\text { always open. }\end{array}$ & 75 & Good \\
\hline & $\begin{array}{l}\text { 8. Can be used by children at } \\
\text { varying speeds. }\end{array}$ & 87,5 & Very good \\
\hline
\end{tabular}




\begin{tabular}{|c|c|c|c|}
\hline \multirow{2}{*}{$\begin{array}{c}\text { 9. The combination of pictures } \\
\text { and writing attracts students. }\end{array}$} & 100 & Very good \\
\cline { 2 - 4 } Total Score & 91,66 & Very good \\
\hline
\end{tabular}

Table 6. Suggestions from the Material Validator

\begin{tabular}{|l|l|}
\hline No. & \multicolumn{1}{|c|}{ Suggestion } \\
\hline 1. & For each picture and illustration is made a statement \\
\hline 2. & Teaching material must include the source of the text. This is to avoid plagiarism. \\
\hline 3. & $\begin{array}{l}\text { It is necessary to re-examine the concepts presented so that they are easy to } \\
\text { understand }\end{array}$ \\
\hline
\end{tabular}

Table 7. Scores of Learning Design Expert Assessments Environmental Based Understanding Reading Module

\begin{tabular}{|c|c|c|c|}
\hline Assessment & Assessment Indicator & $\begin{array}{l}\text { Average } \\
\text { Score }\end{array}$ & Kriteria \\
\hline \multirow[t]{5}{*}{$\begin{array}{l}\text { 1. Leather } \\
\text { Design }\end{array}$} & $\begin{array}{l}\text { 1. The module size is in accordance } \\
\text { with ISO standards (A4, A5 and } \\
\text { B5) with good format, } \\
\text { organization, and attractiveness. }\end{array}$ & 87,5 & Very good \\
\hline & $\begin{array}{l}\text { 2. Changes, including the choice of } \\
\text { letters, illustrations and colors used } \\
\text { are interesting and appropriate. }\end{array}$ & 87,5 & Very good \\
\hline & $\begin{array}{l}\text { 3. Appearance of the face and back } \\
\text { skin has a balanced unity of } \\
\text { patterns. }\end{array}$ & 87,5 & Very good \\
\hline & $\begin{array}{l}\text { 4. Showing perspectives that are } \\
\text { consistent or reflect the character of } \\
\text { learning activities. }\end{array}$ & 62,5 & Good \\
\hline & $\begin{array}{l}\text { 5. Setting the placement of titles, } \\
\text { student identities, illustrations, } \\
\text { logos and others with balanced and } \\
\text { harmonious proportions. }\end{array}$ & 62,5 & Good \\
\hline \multirow[t]{3}{*}{$\begin{array}{l}\text { 2. Skin } \\
\text { Typograp } \\
\text { hy }\end{array}$} & $\begin{array}{l}\text { 6. The font size for the module title, } \\
\text { name identity, class of students, and } \\
\text { character of the activity have a } \\
\text { balanced proportion. }\end{array}$ & 87,5 & Very good \\
\hline & $\begin{array}{l}\text { 7. Do not use too many letter } \\
\text { combinations. }\end{array}$ & 87,5 & Very good \\
\hline & $\begin{array}{|llr|}\text { 8. } & \begin{array}{l}\text { Describes } \\
\text { activities anguage learning } \\
\text { characters. }\end{array} & \\
\end{array}$ & 75 & Good \\
\hline \multirow[t]{2}{*}{$\begin{array}{l}\text { 3. Content } \\
\text { Design }\end{array}$} & $\begin{array}{l}\text { 9. The space between text and } \\
\text { paragraphs of separation is clear. }\end{array}$ & 100 & Very good \\
\hline & $\begin{array}{l}\text { 10. The space between the lines of text } \\
\text { is normal. }\end{array}$ & 100 & Very good \\
\hline
\end{tabular}




\begin{tabular}{|c|c|c|c|}
\hline & $\begin{array}{l}\text { 11. The field of printing and } \\
\text { proportional margins with clear } \\
\text { sentences. }\end{array}$ & 100 & Very good \\
\hline & $\begin{array}{l}\text { 12. Jenjang/hierarki judul, bab, sub } \\
\text { bab, nomor urut, dan angka } \\
\text { halaman teratur dan konsisten. }\end{array}$ & 100 & Very good \\
\hline & $\begin{array}{l}\text { 13. Illustration of the image, the } \\
\text { location of the image, clear and } \\
\text { interesting image captions, and the } \\
\text { exact placement and harmony of } \\
\text { the comparison. }\end{array}$ & 62,5 & Good \\
\hline & $\begin{array}{l}\text { 14. The existence of clear images and } \\
\text { conveying messages. }\end{array}$ & 75 & Good \\
\hline & $\begin{array}{l}\text { 15. Placement of decoration / } \\
\text { illustration as background does not } \\
\text { interfere with title, text, numbers } \\
\text { and pages. }\end{array}$ & 100 & Very good \\
\hline & $\begin{array}{l}\text { 16. The use of variations in letters is not } \\
\text { excessive and attempts to } \\
\text { harmonize the size of letters with } \\
\text { images. }\end{array}$ & 100 & Very good \\
\hline \multirow[t]{4}{*}{$\begin{array}{l}\text { 4. Ilustrasi } \\
\text { Isi }\end{array}$} & $\begin{array}{l}\text { 17. Able to express meanings / } \\
\text { meanings from object illustrations. }\end{array}$ & 100 & Very good \\
\hline & $\begin{array}{l}\text { 18. Innovative products, characterized } \\
\text { by a knowledge and technology } \\
\text { approach. }\end{array}$ & 75 & Good \\
\hline & \begin{tabular}{|l} 
19. Creative, motivational and \\
dynamic.
\end{tabular} & 87,5 & Very good \\
\hline & $\begin{array}{l}\text { 20. The overall presentation of } \\
\text { matching illustrations. }\end{array}$ & 75 & Good \\
\hline \multicolumn{2}{|r|}{ Total Average } & 85,63 & Very good \\
\hline
\end{tabular}

Note: suggestions from design experts both in writing and verbally are listed in table 4.8 .

Table 8. Advice from Design Validators

\begin{tabular}{|c|l|}
\hline No. & \multicolumn{1}{|c|}{ Suggestion } \\
\hline 1. & The cover needs to be beautified and the image is conformed to matter \\
\hline 2. & We recommend that the image size is more enlarged \\
\hline 3. & The colors on the image are still blurred and less brightly coloring \\
\hline
\end{tabular}

The Indonesian teacher's assessment of the development of teaching material products was carried out by Dewi Mandasari, S.Pd., and Harry Akbar, S.Pd., teachers of Junior High School (SMP N) 1 Kuala Medan. Assessment of the reading module understanding the text of the observation report that was developed was carried out to obtain information that would be used to improve the quality of the product being developed. The results of the assessment are in the form of scores on the components of learning that are in accordance with learning Indonesian language especially in reading comprehension of the text of the report on 
observation. The results of the response or response made by the Indonesian language teacher concluded that the reading module understanding the text of the report on the results of environmental based observations was included in the criteria of "very good" with a total percentage of $82.29 \%$.

Table 9. Data Response of Indonesian Language Teachers to Reading Module of Environment-based understanding

\begin{tabular}{|c|c|c|c|}
\hline No. & Indicator & $\begin{array}{l}\text { Average } \\
\text { Score }\end{array}$ & Criteria \\
\hline 1. & $\begin{array}{l}\text { Environment-based modules present the } \\
\text { concepts, theories, and facts of the text of } \\
\text { observation results report }\end{array}$ & 75 & Good \\
\hline 2. & $\begin{array}{l}\text { Presses the aspects of attitude, skill, and } \\
\text { knowledge that learners must learn. }\end{array}$ & 100 & Very good \\
\hline 3. & $\begin{array}{l}\text { This environmentally based module asks } \\
\text { learners questions to recall knowledge and } \\
\text { information from the text of observation results } \\
\text { report. }\end{array}$ & 87,5 & Very good \\
\hline 4. & $\begin{array}{l}\text { Environment-based modules present evaluations } \\
\text { with questions requiring learners to develop self- } \\
\text { intelligence. }\end{array}$ & 75 & Good \\
\hline 5. & $\begin{array}{l}\text { This environmentally based module presents } \\
\text { questions and evaluations using text and images. }\end{array}$ & 87,5 & Very good \\
\hline 6. & $\begin{array}{l}\text { This environmentally based module requires } \\
\text { learners to illuminate answers on each } \\
\text { evaluation of the observation result report text } \\
\text { material. }\end{array}$ & 75 & Good \\
\hline 7. & $\begin{array}{l}\text { Environment-based modules present involving } \\
\text { learners on each evaluation for observation of } \\
\text { observational results report text } \\
\text { material.material }\end{array}$ & 75 & Good \\
\hline 8. & $\begin{array}{l}\text { Environment-based modules correspond to the } \\
\text { staple material contained in the } 2013 \\
\text { Curriculum, measuring the core competence of } \\
\text { learners in and based on core competencies. }\end{array}$ & 75 & Good \\
\hline 9. & $\begin{array}{l}\text { Environment-based modules use easily } \\
\text { understood sentences. }\end{array}$ & 75 & Good \\
\hline 10. & $\begin{array}{l}\text { This environmentally based module is capable of } \\
\text { developing the intelligence learners have. }\end{array}$ & 87,5 & Very good \\
\hline 11. & $\begin{array}{l}\text { Environment-based modules present according } \\
\text { to the learning styles learners have. }\end{array}$ & 75 & Good \\
\hline 12. & $\begin{array}{l}\text { Environment-based modules link science, the } \\
\text { environment, technology to life. }\end{array}$ & 100 & Very good \\
\hline \multicolumn{2}{|r|}{$\begin{array}{c}\text { Total Average Score } \\
\end{array}$} & 82,29 & Very good \\
\hline
\end{tabular}


Table 10. Student Response Data from Individual Trials (3 students) on Environment-Based Reading Module

\begin{tabular}{|c|l|c|c|}
\hline No. & \multicolumn{1}{|c|}{ Indicator } & \multicolumn{1}{|c|}{$\begin{array}{c}\text { Average } \\
\text { Score }\end{array}$} & Criteria \\
\hline 1. & $\begin{array}{l}\text { The physical appearance of this module is very } \\
\text { interesting so I am motivated to read it. }\end{array}$ & 83,33 & Very good \\
\hline 2. & $\begin{array}{l}\text { I can easily understand the instructions for } \\
\text { using this module. }\end{array}$ & 91,67 & Very good \\
\hline 3. & $\begin{array}{l}\text { This module is in accordance with the learning } \\
\text { objectives that I want to achieve. }\end{array}$ & 75,00 & Good \\
\hline 4. & $\begin{array}{l}\text { The order of the material presented in this } \\
\text { module is clear to me. }\end{array}$ & 83,33 & Very good \\
\hline 5. & $\begin{array}{l}\text { The illustration images presented make it easier } \\
\text { for me to understand the material. }\end{array}$ & 91,67 & Very good \\
\hline 6. & $\begin{array}{l}\text { The summary at the end of the learning activity } \\
\text { is clear to me. }\end{array}$ & 83,33 & Very good \\
\hline 7. & $\begin{array}{l}\text { The tasks and evaluation questions in this } \\
\text { module are easy for me to understand. }\end{array}$ & 83,33 & Very good \\
\hline 8. & $\begin{array}{l}\text { This module is able to develop the intelligence } \\
\text { that I have. }\end{array}$ & 75,00 & Good \\
\hline 9. & $\begin{array}{l}\text { This module is able to guide and motivate me } \\
\text { to study independently. }\end{array}$ & 91,67 & Very good \\
\hline 10. & $\begin{array}{l}\text { The size and type used in this module is easy to } \\
\text { read }\end{array}$ & 91,67 & Very good \\
\hline & \multicolumn{2}{|c|}{85,00} & Very good \\
\hline
\end{tabular}

Table 11. Student Response Data from Small Group Trial (9 students) on Environment-based Reading Module.

\begin{tabular}{|c|l|c|c|}
\hline No. & \multicolumn{1}{|c|}{ Indicator } & $\begin{array}{c}\text { Average } \\
\text { Score }\end{array}$ & Criteria \\
\hline 1. & $\begin{array}{l}\text { The physical appearance of this module is very interesting } \\
\text { so I am motivated to read it. }\end{array}$ & 94,44 & Very good \\
\hline 2. & $\begin{array}{l}\text { I can easily understand the instructions for using this } \\
\text { module. }\end{array}$ & 94,44 & Very good \\
\hline 3. & $\begin{array}{l}\text { This module is in accordance with the learning objectives } \\
\text { that I want to achieve. }\end{array}$ & 88,89 & Very good \\
\hline 4. & $\begin{array}{l}\text { The order of the material presented in this module is clear } \\
\text { to me. }\end{array}$ & 91,67 & Very good \\
\hline 5. & $\begin{array}{l}\text { The illustration images presented make it easier for me to } \\
\text { understand the material. }\end{array}$ & 91,67 & Very good \\
\hline 6. & $\begin{array}{l}\text { The summary at the end of the learning activity is clear to } \\
\text { me. }\end{array}$ & 88,89 & Very good \\
\hline 7. & $\begin{array}{l}\text { The tasks and evaluation questions in this module are easy } \\
\text { for me to understand. }\end{array}$ & 88,89 & Very good \\
\hline 8. & This module is able to develop the intelligence that I have. & 88,89 & Very good \\
\hline
\end{tabular}




\begin{tabular}{|c|l|c|c|}
\hline 9. & $\begin{array}{l}\text { This module is able to guide and motivate me to study } \\
\text { independently. }\end{array}$ & 94,44 & Very good \\
\hline 10. & The size and type used in this module is easy to read & 97,22 & Very good \\
\hline \multicolumn{2}{|c|}{ Toal Average } & 91,94 & Very good \\
\hline
\end{tabular}

Table 12. Student Response Data from Limited Field Group Trial (32 students) on Environment-based Reading Module

\begin{tabular}{|c|l|c|c|}
\hline No. & \multicolumn{1}{|c|}{ Indicator } & $\begin{array}{c}\text { Average } \\
\text { Score }\end{array}$ & Criteria \\
\hline 1. & $\begin{array}{l}\text { The physical appearance of this module is very } \\
\text { interesting so I am motivated to read it. }\end{array}$ & 95,31 & Very good \\
\hline 2. & $\begin{array}{l}\text { I can easily understand the instructions for using } \\
\text { this module. }\end{array}$ & 96,88 & Very good \\
\hline 3. & $\begin{array}{l}\text { This module is in accordance with the learning } \\
\text { objectives that I want to achieve. }\end{array}$ & 96,09 & Very good \\
\hline 4. & $\begin{array}{l}\text { The order of the material presented in this module } \\
\text { is clear to me. }\end{array}$ & 95,31 & Very good \\
\hline 5. & $\begin{array}{l}\text { Gambar ilustrasi yang disajikan mempermudah } \\
\text { saya dalam memahami materi. }\end{array}$ & 94,53 & Very good \\
\hline 6. & $\begin{array}{l}\text { The summary at the end of the learning activity is } \\
\text { clear to me. }\end{array}$ & 94,53 & Very good \\
\hline 7. & $\begin{array}{l}\text { The tasks and evaluation questions in this module } \\
\text { are easy for me to understand. }\end{array}$ & 95,31 & Very good \\
\hline 8. & $\begin{array}{l}\text { This module is able to develop the intelligence that } \\
\text { I have. }\end{array}$ & 93,75 & Very good \\
\hline 9. & $\begin{array}{l}\text { This module is able to guide and motivate me to } \\
\text { study independently. }\end{array}$ & 94,53 & Very good \\
\hline 10. & The size and type used in this module is easy to read & 93,75 & Very good \\
\hline \multicolumn{2}{|l|}{ Total Average } & 94,99 & Very good \\
\hline
\end{tabular}

Test the effectiveness of teaching materials for reading modules based on environmental understanding conducted at SMP Negeri 1 Kuala Medan which was tested on students of class VII using the test. The results of the recapitulation of data obtained from the posttest conducted in the control class can be described in table 4.13. following.

Table 13. Data Results Learning Control Class

\begin{tabular}{|c|l|c|}
\hline No & \multicolumn{1}{|c|}{ Students Name } & $\begin{array}{c}\text { Score } \\
\left(\mathbf{X}_{2}\right)\end{array}$ \\
\hline 1 & Azra Arrassyda & 70 \\
\hline 2 & Azzuhra Fakhrunnisa & 60 \\
\hline 3 & Debby Chazlika & 60 \\
\hline 4 & Dwi Gita Ananda & 90 \\
\hline 5 & Faiza Tazkia Shafiqa & 60 \\
\hline 6 & Farid Hasanul Fikri & 65 \\
\hline 7 & Hafaz Fadillah H & 65 \\
\hline
\end{tabular}




\begin{tabular}{|c|c|c|}
\hline 8 & Haura Taqia & 70 \\
\hline 9 & Izathun Nissa & 65 \\
\hline 10 & Khairul Ananda & 65 \\
\hline 11 & Mhd. Farhan Farooq & 75 \\
\hline 12 & Mhd. Faujan Najmi & 55 \\
\hline 13 & Nadia Zahra Rosena & 75 \\
\hline 14 & Natasha Putri Sabrina & 70 \\
\hline 15 & Nisrina Arifin & 65 \\
\hline 16 & Putri Wadda Nabilla & 55 \\
\hline 17 & Rahmawati Ahda Putri & 55 \\
\hline 18 & Reynaldi Alfredo & 70 \\
\hline 19 & Risky Cinta Nayla & 85 \\
\hline 20 & Rujana & 80 \\
\hline 21 & Safira Azzikra & 70 \\
\hline 22 & Sulthan Nabil Z Lubis & 65 \\
\hline 23 & Tanaya Destri & 65 \\
\hline 24 & Lutfiah Zehra & 85 \\
\hline 25 & M. Aryan Syahroni & 80 \\
\hline 26 & M. Naufal Fadhil & 75 \\
\hline 27 & Muhammad Hariz & 65 \\
\hline 28 & Nazifah Amany & 80 \\
\hline 29 & Rafid Ahmad & 70 \\
\hline 30 & Suci Reskia Maulida & 75 \\
\hline 31 & Syahrani Amalia & 65 \\
\hline 32 & Syahrinto Adidin $\mathrm{S}$ & 70 \\
\hline & Total & 2220 \\
\hline
\end{tabular}

The data presented below is data obtained based on tests provided to students regarding reading the understanding of the text of observation results report using textbooks. To determine the range, taken the highest value is then subtracted with the lowest value. In this case, because of the largest data 90 and the smallest data 55, then:

$$
\begin{aligned}
& \text { Range }=(90-55) \\
& =35 .
\end{aligned}
$$

To specify many interval classes, Starges rules are used, i.e.

Total classes $=1+(3,3) \log n$.........(Sudjana:2005) then:

Total classes $=1+(3.3) \log 32$

$$
\begin{aligned}
& =1+(3,3)(1,50) \\
& =5.95 \\
& =6 \text { rows }
\end{aligned}
$$

To determine the length of the interval class used the formula as follows, 
$\mathrm{P}=$ Range

$\overline{\text { Total class }}$

$\mathrm{P}=\frac{35}{6}$

$\mathrm{P}=\frac{35}{6}$

$\mathrm{P}=5.8$ or 6

Table 14. Frequency Distribution of Reading Capability understanding Text Report of Control Class Observation Results

\begin{tabular}{|c|c|c|c|c|c|c|}
\hline Nilai & $\mathbf{X}_{\mathbf{1}}$ & $\mathbf{f}$ & $\mathbf{f X}_{\mathbf{1}}$ & $\mathbf{X}$ & $\mathbf{x}^{\mathbf{2}}$ & $\mathbf{F x}^{\mathbf{2}}$ \\
\hline $55-60$ & 57,5 & 6 & 345 & $-11,6$ & 134,56 & 807,36 \\
\hline $61-66$ & 63,5 & 9 & 571,5 & $-5,6$ & 31,36 & 282,24 \\
\hline $67-72$ & 69,5 & 7 & 486,5 & 0,4 & 0,16 & 1.12 \\
\hline $73-78$ & 75,5 & 4 & 302 & 6,4 & 40,96 & 163,84 \\
\hline $79-84$ & 81,5 & 3 & 244,5 & 12,4 & 153,76 & 461,28 \\
\hline $85-90$ & 87,5 & 3 & 262,5 & 18,4 & 338,56 & 1015,68 \\
\hline & & $\mathbf{3 2}$ & $\sum \boldsymbol{f} \boldsymbol{X}_{\mathbf{1}}=\mathbf{2 2 1 2}$ & & & $\sum \boldsymbol{f x}_{\mathbf{1}}{ }^{2}=\mathbf{2 7 3 1 , 5 2}$ \\
\hline
\end{tabular}

From the table above can be searched for average, standard deviation, and standard error variables namely:

a. Variabel Average (Mean) $\mathrm{X}_{2}$

$$
\mathrm{Mx}_{1}=\frac{\sum f x}{N}=\frac{2212}{32}=69,12
$$

b. Standard Variable Deviation $\mathrm{X}_{2}$

$$
\begin{aligned}
& \operatorname{SDx}_{1}=\sqrt{\frac{\sum f x^{2}}{N}}=\sqrt{\frac{2731,52}{32}}=\sqrt{85,36} \\
& \operatorname{SDx}_{1}=9,23
\end{aligned}
$$

c. Standard Variable Error $\mathrm{X}_{2}$

$$
S E_{M X_{1}}=\frac{S D x_{1}}{\sqrt{N-1}}
$$




$$
\begin{aligned}
& S E_{M X_{1}}=\frac{9,23}{\sqrt{32-1}} \\
& S E_{M X_{1}}=\frac{9,23}{\sqrt{31}} \\
& S E_{M X_{1}}=\frac{9,23}{5,57} \\
& S E_{M X_{1}}=1,65
\end{aligned}
$$

From the results of the calculation above, the data can be categorized into 3 categories namely enough, good and very good. The provisions can be seen in table 15 . The following.

Table 15. Control Class Tendency Identification

\begin{tabular}{|c|c|c|c|}
\hline Range & F. Absolute & F. Relative & Category \\
\hline $85-100$ & 3 & $9,4 \%$ & Veri good \\
\hline $70-84$ & 14 & $43,7 \%$ & Good \\
\hline $55-69$ & 15 & $46,9 \%$ & Fair \\
\hline $40-54$ & 0 & $0 \%$ & Low \\
\hline $0-39$ & 0 & $0 \%$ & Unsatisfied \\
\hline & $\mathbf{3 2}$ & $\mathbf{1 0 0 \%}$ & \\
\hline
\end{tabular}

From the table above, it can be seen that the ability to read the text comprehension of student observation reports includes very good categories of 3 students or $9.4 \%$, good categories as many as 14 students or $43.7 \%$, sufficient categories as many as 15 students or $46.9 \%$. Identify the test results in normal and reasonable categories.

Thus the results of the ability of students to read the understanding of the text of the observation report by using textbooks are classified into sufficient categories with an average value of 69.12 ; standard deviation $=9.23$; standard error $=1.65$ with the lowest value of 55 and the highest value of 90 . Thus the results of the ability of students to read the understanding of the text of the observation report using textbooks are in the sufficient category.

The results of the recapitulation of data obtained from the posttest conducted in the experimental class can be described in table 16. below.

Table 16. Data on the Learning Results of Experiment Class

\begin{tabular}{|c|l|c|}
\hline No & \multicolumn{1}{|c|}{ Students Name } & $\begin{array}{c}\text { Score } \\
\left(\mathbf{X}_{\mathbf{1}}\right)\end{array}$ \\
\hline 1 & Aisyah Aninidita P & 75 \\
\hline 2 & Alifa Raissa Noor & 70 \\
\hline 3 & Aliyah Naila Huda & 65 \\
\hline 4 & Amalia Ayudiyah & 85 \\
\hline 5 & Annisa Adfah & 75 \\
\hline
\end{tabular}




\begin{tabular}{|c|l|c|}
\hline 6 & Arya Prana & 80 \\
\hline 7 & Carla Angelina Putri & 95 \\
\hline 8 & Faqih Alfayed & 85 \\
\hline 9 & Haikal Nugraha Yong & 90 \\
\hline 10 & Indah Azzahra & 70 \\
\hline 11 & Iras Abyan Nugroho & 75 \\
\hline 12 & Khalisha Nailah & 70 \\
\hline 13 & M. Afif Kumala Pontas & 65 \\
\hline 14 & Nabila Sasywa A.S & 60 \\
\hline 15 & Nabila Shalsha & 80 \\
\hline 16 & Najwa Nazihah & 90 \\
\hline 17 & Najwa Nur Salma & 80 \\
\hline 18 & Pocut Guebrina R & 75 \\
\hline 19 & Rizky Darmawan R & 70 \\
\hline 20 & Sashenka Al Azmi & 65 \\
\hline 21 & Shahnaz Fitri Humaira & 80 \\
\hline 22 & T. Nazwa Armaini & 75 \\
\hline 23 & Terang Damarningrat & 85 \\
\hline 24 & Mhd. Rayhan & 90 \\
\hline 25 & Mhd. Zain S Lingga & 80 \\
\hline 26 & Naswa Alya Khaddafi & 75 \\
\hline 27 & Nurul Azura & 70 \\
\hline 28 & Rabiatul Adawiyah Nst & 75 \\
\hline 29 & Rahmat Ardani & 70 \\
\hline 30 & Rifqy Indra Jamal & 80 \\
\hline 31 & Syarifah Sekha & 85 \\
\hline 32 & Tanya Selfira & 75 \\
\hline & & $\mathbf{2 4 6 0}$ \\
\hline
\end{tabular}

In this case, because the biggest data is 95 and the smallest data is 60 , then:

Range $=95-60$

$$
=35
$$

To determine many interval classes, use the Starges rule, i.e.

Total classes $=1+(3.3) \log n$......... (Sudjana: 2005) then:

Total classes $=1+(3.3) \log 32$

$$
\begin{aligned}
& =1+(3.3)(1.50) \\
& =5.95 \\
& =6 \text { lines }
\end{aligned}
$$

To determine the length of the interval class the following formula is used, 
$\mathrm{P}=\underline{\text { Range }}$

(Sudjana: 2005) then:

Total class

$\mathrm{P}=\frac{35}{6}$

$\mathrm{P}=5.8$ or 6 .

Data acquisition from the field can be described in table 17. The following.

Table 17. Frequency Distribution Ability to Read comprehension of the Text Report on Experimental Class Observation Results

\begin{tabular}{|c|c|c|c|c|c|c|}
\hline Score & $\mathbf{X}_{\mathbf{1}}$ & $\mathbf{f}$ & $\mathbf{f X} \mathbf{1}$ & $\mathbf{X}$ & $\mathbf{x}^{\mathbf{2}}$ & $\mathbf{F x}^{\mathbf{2}}$ \\
\hline $60-65$ & 62,5 & 4 & 250 & $-14,25$ & 203,06 & 812,24 \\
\hline $66-71$ & 68,5 & 6 & 411 & $-8,25$ & 68,06 & 408,36 \\
\hline $72-77$ & 74,5 & 8 & 596 & $-2,25$ & 5,06 & 40,48 \\
\hline $78-83$ & 80,5 & 6 & 483 & 3,75 & 14,06 & 84,36 \\
\hline $84-89$ & 86,5 & 4 & 346 & 9,75 & 95,06 & 380,24 \\
\hline $90-95$ & 92,5 & 4 & 370 & 15,75 & 248,06 & 992,24 \\
\hline & & $\mathbf{3 2}$ & $\sum \boldsymbol{f} \boldsymbol{X}_{\mathbf{1}}=\mathbf{2 4 5 6}$ & & & $\sum \mathbf{f x}_{\mathbf{1}} \mathbf{2}=\mathbf{2 7 1 7 , 9 2}$ \\
\hline
\end{tabular}

From the table above can be searched for average, standard deviation, and standard error variables namely:

a. Variabel Average (Mean) $\mathrm{X}_{1}$

$$
\mathrm{Mx}_{1}=\frac{\sum f x}{N}=\frac{2456}{32}=76,75
$$

b. Standard Variable Deviation $\mathrm{X}_{1}$

$$
\begin{aligned}
& \mathrm{SDx}_{1}=\sqrt{\frac{\sum f x^{2}}{N}}=\sqrt{\frac{2717,92}{32}}=\sqrt{84,93} \\
& \mathrm{SDx}_{1}=9,21
\end{aligned}
$$

c. Standard Variabel Error $\mathrm{X}_{1}$

$$
\begin{aligned}
& S E_{M X_{1}}=\frac{S D x_{1}}{\sqrt{N-1}} \\
& S E_{M X_{1}}=\frac{9,21}{\sqrt{32-1}} \\
& S E_{M X_{1}}=\frac{9,21}{\sqrt{31}}
\end{aligned}
$$


$S E_{M X_{1}}=\frac{9,21}{5,57}$

$S E_{M X_{1}}=1,65$

Table 18. Identification of Experiment Class Tendency

\begin{tabular}{|c|c|c|c|}
\hline Range & F. Absolute & R. Relative & Category \\
\hline $85-100$ & 8 & $25 \%$ & Very good \\
\hline $70-84$ & 20 & $62,5 \%$ & Good \\
\hline $55-69$ & 4 & $12,5 \%$ & Fair \\
\hline $40-54$ & 0 & $0 \%$ & Low \\
\hline $0-39$ & 0 & $0 \%$ & Unsatiesfied \\
\hline & $\mathbf{3 2}$ & $\mathbf{1 0 0 \%}$ & \\
\hline
\end{tabular}

One of the analytical requirements to be met in order to use parametric statistics is that the data spread of each research variable must be normally distributed. Normal testing of no data deployment can be done using the Lilliefors test. The normal terms to be met are $L_{\text {count }}<$ $L_{\text {table }}$ at significant rates $\alpha=0.05$. Here is the $\mathrm{X} 2$ variable normality test table.

Table 19. Control Class Data Normality Test (X2)

\begin{tabular}{|c|c|c|c|c|c|c|c|}
\hline No & $\mathbf{X}$ & $\mathbf{F}$ & $\mathbf{F k u m}$ & $\mathbf{Z i}$ & $\mathbf{F}(\mathbf{Z i})$ & $\mathbf{S}(\mathbf{Z i})$ & $\mathbf{L}$ \\
\hline 1 & 55 & 3 & 3 & $-1,52$ & 0,0643 & 0,0937 & 0.0294 \\
\hline 2 & 60 & 3 & 6 & $-0,98$ & 0,1635 & 0,1875 & 0,024 \\
\hline 3 & 65 & 9 & 15 & $-0,44$ & 0,3300 & 0,4687 & 0,1387 \\
\hline 4 & 70 & 7 & 22 & 0,09 & 0,5359 & 0,6875 & $\mathbf{0 , 1 5 1 6}$ \\
\hline 5 & 75 & 4 & 26 & 0,63 & 0,7357 & 0,8125 & 0,0768 \\
\hline 6 & 80 & 3 & 29 & 1,17 & 0,8790 & 0,9062 & 0,0272 \\
\hline 7 & 85 & 2 & 31 & 1,72 & 0,9573 & 0,9687 & 0,0114 \\
\hline 8 & 90 & 1 & 32 & 2,26 & 0,9881 & 1 & 0,0119 \\
\hline & & $\mathbf{3 2}$ & & & & & \\
\hline
\end{tabular}

It is known that the experimental class average $=69.12$, Standard Deviation $=9.23$ and $\mathrm{N}=32$.

1. Raw Numbers (Z1)

$\mathrm{Z}_{1}=\frac{X-\bar{X}}{S D x}$

$=\frac{55-69,12}{9,23}$ Thus to search for $\mathrm{Zi} \mathrm{next}$.

2. By using the normal distribution list of table $\mathrm{Z}$, with a value of -1.52 , it is obtained 0.0643 . Thus to look for the next $\mathrm{F}(\mathrm{Zi})$.

1. 3. $\mathrm{S}(\mathrm{Zi})==\frac{f K u m}{N}$ 


$$
\begin{aligned}
& =\frac{3}{32} \\
& =0,0937
\end{aligned}
$$

Thus to look for the next $\mathrm{S}(\mathrm{Zi})$.

$$
\text { 4. } \begin{aligned}
\mathrm{L} & =\mathrm{F}(\mathrm{Zi})-\mathrm{S}(\mathrm{Zi}) \\
& =0.0643-0.0937 \\
& =-0,0294(\text { absolute to be } 0,0294)
\end{aligned}
$$

Thus to search for the next $\mathrm{L}$.

Based on the table above, it can be obtained the price of Lhitung $=0.151$, from the critical table $\mathrm{L}$ for the Lilliefors test with $\mathrm{N}=32$ and the real degree $\alpha=0.05$ in can $\mathrm{L}_{\text {table }}=0.1566$. Once compared it turns out that $\mathrm{L}_{\text {Count }}<\mathrm{L}_{\text {talble }}$ or $0.11516<0.1566$. It can therefore be inferred that the X2 varabel data is normally distributed.

To test the normality test of X1 variable results can be used Lilliefors test. Here is the $\mathrm{X} 1$ variable normality test table.

Table 20. Experiment Class Data Normality Test (X1)

\begin{tabular}{|c|c|c|c|c|c|c|c|}
\hline No & $\mathbf{X}$ & $\mathbf{F}$ & $\mathbf{F k u m}$ & $\mathbf{Z i}$ & $\mathbf{F}(\mathbf{Z i})$ & $\mathbf{S}(\mathbf{Z i})$ & $\mathbf{L}$ \\
\hline 1 & 60 & 1 & 1 & $-1,81$ & 0,0351 & 0,0312 & 0,0039 \\
\hline 2 & 65 & 3 & 4 & $-1,27$ & 0,1020 & 0,125 & 0,023 \\
\hline 3 & 70 & 6 & 10 & $-0,73$ & 0,2327 & 0,3125 & 0,0798 \\
\hline 4 & 75 & 8 & 18 & $-0,19$ & 0,4246 & 0,5625 & $\mathbf{0 , 1 3 7 9}$ \\
\hline 5 & 80 & 6 & 24 & 0,35 & 0,6368 & 0,75 & 0,1132 \\
\hline 6 & 85 & 4 & 28 & 0,89 & 0,8133 & 0,875 & 0,0617 \\
\hline 7 & 90 & 3 & 31 & 1,43 & 0,9236 & 0,9687 & 0,0451 \\
\hline 8 & 95 & 1 & 32 & 1,98 & 0,9761 & 1 & 0,0239 \\
\hline & & $\mathbf{3 2}$ & & & & & \\
\hline
\end{tabular}

It is known that the experimental class average $=76.75$, Standard Deviation $=9.21$ and $\mathrm{N}=32$.

1. Raw Numbers (Z1)

$$
\begin{aligned}
& \mathrm{Z} 1=\frac{X-\bar{X}}{S D x} \\
& =\frac{60-76,75}{9,21} \\
& =-1,81
\end{aligned}
$$

So to look for Zi next.

2. By using the normal distribution list of table $\mathrm{Z}$, with a value of -1.81 it is obtained 0.0351 . Thus to look for the next $\mathrm{F}(\mathrm{Zi})$. 
1. 3. $\mathrm{S}(\mathrm{Zi})=\frac{f K u m}{N}$

$$
\begin{aligned}
& =\frac{1}{32} \mathrm{~h} \\
& =0,0312
\end{aligned}
$$

Thus to look for the next $\mathrm{S}(\mathrm{Zi})$.

4. $\mathrm{L}=\mathrm{F}(\mathrm{Zi})-\mathrm{S}(\mathrm{Zi})$

$$
\begin{aligned}
& =0.0351-0.0312 \\
& =-0,0039(\text { absolute to } 0.0039)
\end{aligned}
$$

Thus to search for the next $\mathrm{L}$.

Based on the table above, it can be obtained the price of $\mathrm{L}_{\text {count }}=0.1379$, from the critical table $\mathrm{L}$ for the Lilliefors test with $\mathrm{N}=32$ and the real degree $\alpha=0.05$ in can $\mathrm{L}_{\text {table }}=0.1566$. Once compared it turns out that $\mathrm{L}_{\text {count }}<\mathrm{L}_{\text {table }}$ or $0.1379<0.1566$. It can therefore be inferred that the $\mathrm{X}_{1}$ varabel data is normally distributed.

The August homogeneity of variance is elaborated to test variable similarities. To test the homogeneity used was Bartlet's test. The calculations were as follows.

Known:

$S^{2} X_{1}=(9,21)^{2}=84,82$

$S^{2} X_{2}=(9,23)^{2}=85,19$

Degree of freedom $(\mathrm{dk})$

$$
\begin{aligned}
\mathrm{dk} & =\mathrm{N}-1 \\
& =32-1 \\
& =31
\end{aligned}
$$

After obtaining the prices needed for the Bartlet test, then the combined variance is calculated from all samples $\left(\mathrm{S}^{2}\right)$, unit B prices, and Chi Squares statistics $\left(\mathrm{X}^{2}\right)$ are used. The following are the results of data homogeneity calculations for each study variable. 
Table 21. Prices That Need To Test Bartlett

\begin{tabular}{|c|c|c|c|c|c|}
\hline Sample & $\mathbf{D k}$ & $\mathbf{1 / d k}$ & $\mathbf{S}_{\mathbf{i}}{ }^{2}$ & $\mathbf{L o g} \mathbf{S}_{\mathbf{i}}^{\mathbf{2}}$ & $(\mathbf{d k}) \mathbf{L o g} \mathbf{S i}_{\mathbf{i}}^{\mathbf{2}}$ \\
\hline $\mathrm{X}_{1}$ & 31 & 0,03 & 84,82 & 1,92 & 59,52 \\
\hline $\mathrm{X}_{2}$ & 31 & 0,03 & 85,19 & 1,93 & 59,83 \\
\hline & $\mathbf{6 2}$ & & & & $\mathbf{1 1 9 , 5 3}$ \\
\hline
\end{tabular}

a. Sample Combined Variance

$$
\begin{aligned}
S^{2} & =\frac{\sum\left(n_{1}-i\right) S_{1}{ }^{2}}{\sum\left(n_{i}-1\right)} \\
& =\frac{\left(n x_{1}-1\right) S x^{2}+\left(n x_{2}-1\right) S x_{2}{ }^{2}}{\left(n x_{1}+n x_{2}\right)-2} \\
& =\frac{(31)(84,82)+(31)(85,19)}{62} \\
& =\frac{2629,42+2640,89}{62} \\
& =\frac{5270,31}{62} \\
& =85,01
\end{aligned}
$$

$\log S^{2}=\log 85,01=1,93$

b. Unit price $B$

$$
\begin{aligned}
\mathrm{B} & =\log \mathrm{S}^{2} \sum\left(n_{1}-1\right) \\
& =(1,93)(63) \\
& =121,59
\end{aligned}
$$

c. Bartlett's test with Chi Squared formula

$$
\begin{aligned}
X^{2} & =\ln 10\left\{B-\sum\left(n_{1}-1\right) \log S_{I}^{2}\right\} \\
& =(2,3026)(121,59-119,53) \\
& =(2,3026)(2,06)=4,74
\end{aligned}
$$


From the above calculation, $X^{2}$ (Chi Squared) count is 4.74 . Price of $X 2$ table at $95 \%$ confidence level with dk 31 is 43.7 . It turns out that $X^{2}$ counts $<X^{2}$ table which is $4.74<43.7$. This proves that the population variance is homogeneous.

After testing the normality and homogeneity carried out and it turns out that the two variables are normally distributed and have the same variance (homogeneous). Thus the use of " $t$ " test statistics can be done with the following formula.

$$
t_{0}=\frac{M_{1}-M_{2}}{S E_{M_{1}-M_{2}}}
$$

$$
\begin{aligned}
\text { Where }:=S E_{M_{1}-M_{2}}= & \sqrt{\left(S E_{M_{1}}\right)^{2}+\left(S E_{M_{2}}\right)^{2}} \\
& =\sqrt{(1,65)^{2}+(1,65)^{2}} \\
& =\sqrt{2,72+2,72} \\
& =\sqrt{5,44} \\
& =2,33
\end{aligned}
$$

So:

$$
t_{0}=\frac{M_{1}-M_{2}}{S E_{M_{1}-M_{2}}}
$$$$
t_{0}=\frac{76,75-69,12}{2,33}
$$

$t_{0}=\frac{7,63}{2,33}$

$t_{0}=3,27$

After $t_{0}$ is obtained, then consulted with table $t$ at a significant level of $5 \%$ with $\mathrm{dk}=(\mathrm{N} 1$ $+\mathrm{N} 2)-2=(32+32)-2=62$. In table $\mathrm{t}$ with $\mathrm{dk}=62$ a significant level of $5 \%=2$ is obtained. 00 . Because t0 obtained is greater than ttabei, which is 3.27>2.00, the null hypothesis (Ho) is rejected and the alternative hypothesis $(\mathrm{Ha})$ is accepted. This proves that the module reading environment-based understanding has a positive effect on improving students' ability to read comprehension of the text of the observation report. 


\section{Conclusion}

The multiple intelligences based module product developed on the observation report text material for seventh grade students of AL-Azhar School fulfills the requirements and is feasible to use based on the validation of the material experts including the feasibility of content with an average of $92.19 \%$ in very good criteria, feasibility of presentation with an average of $100 \%$ on very good criteria, the feasibility of multiple intelligences with an average of $96.87 \%$ on very good criteria, the feasibility of language with an average of $91.66 \%$ on very good criteria, and validation of design experts with an average $84.35 \%$ in very good criteria.

The pattern of writing modules based on multiple intelligences in the text material of the observation report is classified as very good and in accordance with the needs of students, judging from the response of 2 teachers who average $82.29 \%$ with very good criteria and 32 students having a percentage of $94.44 \%$ with criteria are very good.

The use of multiple intelligences based writing modules is more effective in improving student learning outcomes, this is indicated by the learning outcomes of students who are taught to use a module developed which is higher by 2460 with an average of $76.75 \%$ compared to the average value of students using 2220 textbooks. an average of $69.12 \%$.

\section{References}

Amstrong, T. 2009. Kecerdasan Multipel di dalam Kelas (Edisi Ketiga). Jakarta: Indeks.

Ariyanti, Kentjananingsih, Raharjo. 2013. Pengembangan Lembar Kerja Siswa Berbasis ICT pada Materi Sistem Syaraf untuk Siswa Kelas XI RSBI. Jurnal BioEdu 2 (1): 59-63.

Bowles, Terry. 2008. Self-rated Estimates of Multiple Intelligences Based on Approaches to Learning. Australian Journal OF Educational \& Development Psychology, (online), Vol $8 \mathrm{http} / / /$ www.newcastle.eedu.au/group/ajedp/

Chatib, M. 2012. Sekolahnya Manusia. Bandung : Kaifa Learning.

Chatib, M.. 2013. Gurunya Manusia. Bandung : Kaifa Learning.

Depdiknas. 2006. Kurikulum Tingkat Satuan Pendidikan. Jakarta: Departemen Pendidikan Nasional. Jakarta.

Depdiknas, 2006. Peraturan Menteri Pendidikan Nasional Nomor 22 Tahun 2006. Tentang Standar Isi. Jakarta: Depdiknas

Dewi, Mela. 2015. Pengembangan Buku Ajar Biologi Berbasis Multiple Intelligences Kelas VIII. Unimed.

Gardner, Howard. 2003. Multiple Intelligences (Kecerdasan Majemuk). Batam: Interaksara

Ibnain, S. S. K., \& Hadban, A.D. 2013. Implications of Multiple Intelligences Theory in ELT Field, (online), Vol 3 No 4 http://ijhssnett.com

Karsli \& Sahin. 2009. Developing Worksheet Based on Science Process Skills: Factors Affecting Solubility Asia-Pasific Forum on Science Learning and Teaching. 10 (1): 15

Lucy. 2010. Mendidik Sesuai dengan Minat dan Bakat Anak. Jakarta: Tangga Pustaka.

Mahsun. 2014. Teks dalam Pembelajaran Bahasa Indonesia (Kurikulum 2013). Jakarta: PT Raja Grafindo Perkasa.

Murdiyani, Isni. 2012. Pembelajaran Biologi Menggunakan Metode E-Learning Berbasis Multiple Intelligences pada Materi Sistem Gerak Manusia. Innovative Journal of Curriculum and Educational Technology, (online), Vol 1 No 1, http://journal.unnes.ac.id/sju/index.php/ujet 
OECD PISA Databese. 2012. National Center for Education Statistics. http://noes.ed.gov/surveys/pisa/pisa2012

Prastowo, A. 2012. Panduan Kreatif Membuat Bahan Ajar Inovatif. Yogyakarta: Diva Press.

Prashnig, Barbara. 2005. Learning Test VS Multiple Intelligences, Two Concepts for Enhancing Learning and Teaching (online). Issue $9 \mathrm{http}$ ://creativelearningcentre.com

Prianto \& Harnoko. 1997. Perangkat Pembelajaran. Jakarta: Departemen Pendidikan dan Kebudayaan.

Russel, Lou. 2011. The Accelerated Learning Fieldbook. Bandung: Nusamedia

Rooijakkers, Ad. 2003. Mengajar dengan Sukses: Petunjuk untuk Merencanakan dan Menyampaikan Pengajar. Jakarta: Grasindo.

Said. Budimanjaya. 2015. 95 Strategi Mengajar Multiple Intelligences. Jakarta: PRENADAMEDIA GROUP.

Sudjana, N. 2005. Penilaian Hasil Proses Belajar Mengajar. Bandung: PT: remaja Rosdakarya.

Sugiyono, 2011. Metode Penelitian Pendidikan Pendekatan Kuantitatif, Kualitatif dan $R \& D$. Bandung: Alfabeta.

Septiani, D. 2013. Pengembangan Lembar Kerja Siswa Berbasis Multiple Intelligences Pada Materi Pertumbuhan Dan Perkembangan Di Smp Negeri 1 Pengadegan Purbalingga. Skripsi. Semarang: Jurusan Biologi FMIPA UNNES.

Slameto. 1999. Evaluasi Pendidikan. Jakarta: Bumu Aksara.

Trianto. 2011. Mendesain Model Pembelajaran Inovatif-Integratif. Jakarta: Kencana.

UU RI No. 14 TH 2005 Tentang Guru dan Dosen, UU RI No. 20 TH 2003

Tentang SISDIKNAS dilengkapi Peraturan Mendiknas No. 11 TH 2005

Tentang Buku Teks Pelajaran, Peraturan Pemerintah No. 19 TH 2005

Tentang Standar Nasional Pendidikan. 2006 Bandung: Citra Umbara

Urooj T., \& Malik, S. K. 2012. Assesment of Multiple Intelligences Managed in English Text Book of Primary Level, (online), Vol 1 Issue 2, http://ijee.org

Waterhouse, Lynn. 2006. Multiple Intelligences, the Mozart Effect, and Emotional Intelligences: A Critical Review, (online), 41 (4), http://graduatestudenthelp.com

Wijayanti. 2013. Analisis Isi Lembar Kerja Siswa (LKS) Bahasa Indonesia Jenjang SMP (Kelas VII, VIII, dan IX) Semester Gasal yang Disusun oleh Tim MGMP Kota Malang Tahun Pelajaran 2012//2013.

Wulan. 2008. Permasalahan yang Dihadapi oleh Para Guru Sains dalam Melaksanakan Asessmen Kinerja di SMP. Jurnal Pendidikan Pembelajaran 6:2 